\title{
An Analysis of Crystalline Admixtures in Terms of Their Influence on the Resistance of Cementitious Composites to Aggressive Environments
}

\author{
Ámos Dufka', Nikol Žižkovái", Jiří Brožovský \\ ${ }^{1}$ Department of Technology of Building Materials and Components, Faculty of Civil Engineering, Brno University of Technology, \\ Veveři 95, 60200 Brno, Czech Republic \\ 2 Department of Structural Mechanics, Faculty of Civil Engineering, VSB - Technical University of Ostrava, Ludvika Podeste 1875/17, \\ 70833 Ostrava-Poruba, Czech Republic \\ * Corresponding author, e-mail: zizkova.n@fce.vutbr.cz
}

Received: 05 June 2019, Accepted: 06 November 2020, Published online: 23 November 2020

\begin{abstract}
This paper describes the influence of crystalline admixtures on the chemical resistance of cement composites exposed to aggressive environments. The effect of the crystalline admixtures was determined by a series of physical-mechanical and innovative physicalchemical methods. Specifically, this concerned the measurement of flexural strength, compressive strength, determination of the dynamic modulus of elasticity by the ultrasonic pulse velocity test, and an analysis of the internal structure by mercury intrusion porosimetry and x-ray computed tomography. Physical-chemical analyses were also performed; namely an x-ray diffraction analysis to determine the mineralogical composition and electron microscopy to examine the microstructure. The use of non-destructive testing methods (ultrasonic pulse velocity test and computed tomography) made it possible to compare the properties of the same specimens for 16 months. The specimens were stored in reference laboratory conditions, a sodium sulphate solution and an ammonium chloride solution. The physical-mechanical tests and physical-chemical analyses clearly showed the benefit that crystalline admixtures have for the resistance of cementitious composites attacked by chemically aggressive solutions without affecting the fresh-mixture rheology or decreasing the strength of the composites.
\end{abstract}

\section{Keywords}

cementitious composites, crystalline admixtures, aggressive environment, resistance, modern diagnostic methods

\section{Introduction}

Contemporary civil engineering demands materials of excellent properties, which means not only good strength but also durability under all usage conditions.

One of the useful principles that can be used to improve the resistance of cement composites to adverse environments involves using suitable admixtures to prevent the ingress of aggressive agents through the capillary pore structure.

In recent years, researchers have been focusing on self-healing in ordinary concrete [1], self-healing engineered with fibber reinforcement [2-4], bacteria-based self-healing concrete [5], super absorbent polymers [6], self-healing of mortars using tubular capsules made from glass and ceramics filled with a healing agent [7], self-healing effect of microcapsules with an oil core and a silica gel shell [8], and other admixtures such as flyash [9], nanographite [10-12], marble powder [12-16] and brick powder [14-16]. In the latter case, the self-healing occurs mainly by the filling of cracks, swelling and expansion, and improved hydration and re-crystallization [1].

The self-healing mechanism requires a sufficient amount of water to be present, especially when chemical agents were added to promote the growth of crystals inside the cracks.

One of the promising new technologies for protecting cementitious composites against aggressive environments is the use of crystalline admixtures, which ACI TC 212 [17] classifies as a type of permeability-reducing admixtures (PRA). Crystalline admixtures (CA) are hydrophilic, i.e., they react easily with water, in contrast to water-repellent or hydrophobic products [18]. The crystalline formations produced by CA become a permanent part of the cement matrix $[6,17]$. 
Their behavior is still not fully understood. In fact, the ACI TC 212 report [17] states that the concrete compounds that react with $\mathrm{CA}$ are tricalcium silicates, although other authors [18] state calcium hydroxide as the reactive. The process, according to [17], following equation (Eq. (1)), where a crystalline promoter $M_{x} R_{x}$ reacts with tricalcium silicates and water to produce modified calcium silicates hydrates and a pore-blocking precipitate $\mathrm{M}_{\mathrm{x}} \mathrm{CaR}_{\mathrm{x}}-\left(\mathrm{H}_{2} \mathrm{O}\right)_{\mathrm{x}}$.

$$
\begin{aligned}
& 3 \mathrm{CaO}-\mathrm{SiO}_{2}+\mathrm{M}_{\mathrm{x}} \mathrm{R}_{\mathrm{x}}+\mathrm{H}_{2} \mathrm{O} \rightarrow \mathrm{Ca}_{\mathrm{x}} \mathrm{SiO}_{\mathrm{x}} \mathrm{R}-\left(\mathrm{H}_{2} \mathrm{O}\right)+ \\
& \mathrm{M}_{\mathrm{x}} \mathrm{CaR}_{\mathrm{x}}-\left(\mathrm{H}_{2} \mathrm{O}\right)_{\mathrm{x}}+\mathrm{M}_{\mathrm{x}} \mathrm{CaR}_{\mathrm{x}}-\left(\mathrm{H}_{2} \mathrm{O}\right)_{\mathrm{x}}
\end{aligned}
$$

The research described herein focused on assessing the effect of this type of CA.

\section{Materials and experimental procedures}

\subsection{Specimen preparation and exposure to aggressive environments}

This particular experiment analyzed the chemical resistance delivered by CA using fine-grained cement composites (aggregate fraction according to CSN EN 196-1 [19]).

It tested CA-modified materials as well as materials modified by a combination of the admixtures and dispersed reinforcement.

One of the important points of the research was a comparison of the modified materials with unmodified ones, i.e. with only a pure cement matrix (identified as I through III). Table 1 shows the composition of the test mixtures.

Water was added so as to keep the workability more or less constant, following the determination of consistence of fresh mortar according to CSN EN 1015-3 [20] was $160 \pm 10 \mathrm{~mm}$.

Table 2 shows the values of consistency determined by the flow table test.

The tests have shown that the workability of the fresh mixtures is more affected by the presence of dispersed reinforcement rather than the crystalline admixture, which has only a minor influence on this parameter.

The mixtures contained the following raw materials:

Cement CEM I 42.5 $\mathrm{R}$ was used as binder, sand was added in accordance with CSN EN 196-1 [19] and the CA was XYPEX Admix (XYPEX CHEMICAL CORPORATION, Richmond B.C., Canada). The second batch of specimens was made with polypropylene fibres Fibrin 3/15 (KrampeHarex CZ, s.r.o., Czech Republic).

Following a procedure described in ČSN EN 196-1 [19] the mixtures were cast into prisms of $40 \times 40 \times 160 \mathrm{~mm}$.
The specimens were stored for 28 days at a temperature of $23^{\circ} \mathrm{C}$ and relative humidity of $95 \%$. At the age of 28 days they were placed in aggressive solutions; see Table 3 for details. Some of the specimens remained in laboratory conditions throughout the experiment and served for reference.

The concentration of the solutions was monitored throughout the experiment and kept at a constant level.

\subsection{Testing procedures and analysis}

At selected time intervals (exposure of 3, 6, 12 and 15 months), some of the specimens were removed from their environments and subjected to physical-mechanical and physical-chemical tests:

- Determination of flexural strength $\left(R_{f}\right)$ and compressive strength $\left(R_{c}\right)$ according to [19],

- Determination of the dynamic modulus of elasticity; it was measured every month by the ultrasonic pulse velocity test. The ultrasonic pulse velocity test is a non-destructive method used mainly in concrete testing and is standardized by ISO 1920-7 [21], ASTM C597 [22], CSN EN 12504-4 [23], CSN 731371 [24], CSN 731380 [25]. The parameters measured by the ultrasonic pulse velocity test can be used to determine physical-mechanical properties (dynamic modulus of elasticity, strength estimation) as well as changes in the internal structure due to

Table 1 Composition of the mortars per $\mathrm{m}^{3}$

\begin{tabular}{lccccc}
\hline Mix. ID & $\begin{array}{c}\text { Cement } \\
{[\mathrm{kg}]}\end{array}$ & $\begin{array}{c}\text { Sand } \\
{[\mathrm{kg}]}\end{array}$ & $\begin{array}{c}\text { CA } \\
{[\mathrm{kg}]}\end{array}$ & $\begin{array}{c}\text { PP Fibres } \\
{[\mathrm{kg}]}\end{array}$ & $\begin{array}{c}\text { Water } \\
{[\mathrm{L}]}\end{array}$ \\
\hline I & 512 & 1535 & 0 & 0 & 256 \\
II & 511 & 1533 & 3 & 0 & 256 \\
III & 510 & 1531 & 8 & 0 & 255 \\
IV & 511 & 1533 & 0 & 1 & 262 \\
V & 511 & 1532 & 3 & 1 & 264 \\
VI & 510 & 1539 & 8 & 1 & 263 \\
\hline
\end{tabular}

Table 2 Consistency of fresh mixtures

\begin{tabular}{lcccccc}
\hline Mix. ID & I & II & III & IV & V & VI \\
\hline Flow value $[\mathrm{mm}]$ & 158 & 159 & 158 & 155 & 153 & 157 \\
\hline
\end{tabular}

Table 3 Test environments, details about the aggressive solutions

\begin{tabular}{lc}
\hline Environment ID & Specification \\
\hline $\begin{array}{l}\text { Laboratory conditions - } \\
\text { reference }\end{array}$ & $\begin{array}{c}\text { temperature of } 23{ }^{\circ} \mathrm{C} \text { and relative } \\
\text { humidity of } 95 \%\end{array}$ \\
$\begin{array}{l}\text { Sodium sulphate solution } \\
\text { Ammonium chloride }\end{array}$ & concentration of $36000 \mathrm{mg} \mathrm{of} \mathrm{SO}_{4}{ }^{2-}$ \\
solution & \\
\hline
\end{tabular}


various forms of external attack (freeze-thaw resistance test, exposure to aggressive media or high temperatures), defects, or homogeneity.

The following parameters measured by the ultrasonic pulse velocity test can be used to assess changes in the internal structure of a material:

- Ultrasonic pulse velocity - measurement and evaluation according to ISO 1920-7 [21], ASTM C597 [22],CSN EN 12504-4 [23].

- Young's modulus of elasticity - measurement and evaluation according to ASTM C597 [22], CSN 731371 [24].

- Relative dynamic modulus of elasticity - measurement and evaluation according to CSN 731380 [25].

Various other authors have used the ultrasonic pulse velocity test to assess changes in the internal structure of concrete and other building materials, e.g. [26-30].

The research described here used this method (as described in CSN 731380 [25]) to observe changes in the internal structure of secondary crystallization-modified cement composites exposed to aggressive environments. These changes were assessed based on changes in the relative dynamic modulus of elasticity depending on time of exposure.

Test equipment - an ultrasonic tester with an accuracy of $0.1 \mu \mathrm{s}$ and natural transducer frequency of $150 \mathrm{kHz}$. Measurement procedure and evaluation - the specimens with the dimensions of $40 \times 40 \times 160 \mathrm{~mm}$ were tested at 30 -day intervals by direct transmission in the longitudinal direction. The measurement outcome is the transit time T. Relative dynamic modulus of elasticity $R D M U_{P P T, t i}(\mathrm{CSN} 731380$ [25]) was calculated using Eq. (2):

$R D M_{U P P T, n}=\left(\frac{t_{S, 0}}{t_{S, n}}\right)^{2} .100$,

where:

$R D M_{U P P T, n}$ - relative dynamic modulus of elasticity calculated from the ultrasonic pulse transit time after $n$ months of exposure to an aggressive medium [\%]. $t_{S, 0}$ - initial transit time $[\mu \mathrm{s}]$;

$t_{S, n}$ - ultrasonic pulse transit time after $\mathrm{n}$ months of exposure to an aggressive medium $(n=1$ through 14 months) $[\mu \mathrm{s}]$;

- The internal structure was analyzed using mercury intrusion porosimetry and x-ray computed tomography (CT) using the method described in [31].
An x-ray (CT) image analysis showed to be a powerful technique to study pore-related characteristics and create simulations of cementitious materials [32-34].

- Physical-chemical analyses involved the determination of mineralogical composition using x-ray diffraction (XRD) and differential thermal analysis (DTA). The microstructure was also examined by scanning electron microscopy. These tests were performed following a method described in [35].

The use of non-destructive testing methods (ultrasonic pulse velocity test and computed tomography) made it possible to make tests on the same specimens. In terms of determining the durability of building materials, this approach is fairly unique and very effective.

\section{Experiment results}

\subsection{Physical-mechanical parameters}

Table 4 shows the results of flexural and compressive strength tests for specimens stored in laboratory conditions and Tables 5 and 6 show the strength of specimens attacked by the aggressive media (sulphates and chlorides). The values in the tables are averages made from test sets, each consisting of six specimens.

\section{a) Aggressive sulphate environment}

Graphs 1 and 2 show changes in flexural and compressive strength in dependence on the length of exposure to the aggressive environment and type of material. The strength

Table 4 Strength - laboratory conditions

\begin{tabular}{|c|c|c|c|c|c|c|}
\hline \multirow[b]{2}{*}{$\begin{array}{l}\text { Mix. } \\
\text { ID }\end{array}$} & \multicolumn{6}{|c|}{ Age } \\
\hline & & $\begin{array}{c}1 \\
\text { month }\end{array}$ & $\begin{array}{c}4 \\
\text { months }\end{array}$ & $\begin{array}{c}7 \\
\text { months }\end{array}$ & $\begin{array}{c}13 \\
\text { months }\end{array}$ & $\begin{array}{c}16 \\
\text { months }\end{array}$ \\
\hline \multirow{2}{*}{ I } & $R_{f}[\mathrm{MPa}]$ & 9.8 & 11.2 & 11.4 & 12.0 & 12.1 \\
\hline & $R_{c}[\mathrm{MPa}]$ & 53.2 & 54.1 & 54.4 & 54.7 & 54.7 \\
\hline \multirow{2}{*}{ II } & $R_{f}[\mathrm{MPa}]$ & 9.7 & 10.7 & 11.1 & 11.4 & 11.6 \\
\hline & $R_{c}[\mathrm{MPa}]$ & 55.5 & 56.2 & 56.4 & 56.7 & 56.8 \\
\hline \multirow{2}{*}{ III } & $R_{f}[\mathrm{MPa}]$ & 9.4 & 11.1 & 11.5 & 11.8 & 12.1 \\
\hline & $R_{c}[\mathrm{MPa}]$ & 52.3 & 53.5 & 53.9 & 54.1 & 54.3 \\
\hline \multirow{2}{*}{ IV } & $R_{f}[\mathrm{MPa}]$ & 9.9 & 11.6 & 11.9 & 12.1 & 12.3 \\
\hline & $R_{c}[\mathrm{MPa}]$ & 53.1 & 53.8 & 54.2 & 54.7 & 55.1 \\
\hline \multirow{2}{*}{ V } & $R_{f}[\mathrm{MPa}]$ & 9.5 & 10.7 & 11.2 & 11.9 & 12.4 \\
\hline & $R_{c}[\mathrm{MPa}]$ & 53.6 & 54.1 & 54.7 & 55.1 & 55.3 \\
\hline \multirow{2}{*}{ VI } & $R_{f}[\mathrm{MPa}]$ & 10.1 & 11.4 & 11.8 & 11.8 & 12.4 \\
\hline & $R_{c}[\mathrm{MPa}]$ & 52.6 & 52.7 & 53.7 & 53.9 & 54.1 \\
\hline
\end{tabular}

Note: Table 4 shows values of flexural strength $\left(R_{f}\right)$ and compressive strength $\left(R_{c}\right)$, which served as reference during evaluation. Specimens were placed in the aggressive environments at an age of 1 month; the exposed specimens were thus compared with references of 1 month + exposure time. 
Table 5 Strength - Exposure to a sulphate solution

\begin{tabular}{lccccc}
\hline Mix. ID & $\begin{array}{c}\text { Exposure } \\
\text { time }\end{array}$ & $\begin{array}{c}3 \\
\text { months }\end{array}$ & $\begin{array}{c}6 \\
\text { months }\end{array}$ & $\begin{array}{c}12 \\
\text { months }\end{array}$ & $\begin{array}{c}15 \\
\text { months }\end{array}$ \\
\hline I & $R_{f}[\mathrm{MPa}]$ & 12.6 & 12.1 & 11.0 & 8.4 \\
& $R_{c}[\mathrm{MPa}]$ & 54.1 & 52.6 & 49.8 & 47.5 \\
II & $R_{f}[\mathrm{MPa}]$ & 12.5 & 12.1 & 11.8 & 10.0 \\
& $R_{c}[\mathrm{MPa}]$ & 56.2 & 54.3 & 50.1 & 49.4 \\
III & $R_{f}[\mathrm{MPa}]$ & 12.7 & 12.4 & 12.1 & 10.5 \\
& $R_{c}[\mathrm{MPa}]$ & 53.5 & 51.1 & 51.8 & 51.0 \\
IV & $R_{f}[\mathrm{MPa}]$ & 12.9 & 12.6 & 10.1 & 9.5 \\
& $R_{c}[\mathrm{MPa}]$ & 51.5 & 51.7 & 50.9 & 48.7 \\
V & $R_{f}[\mathrm{MPa}]$ & 12.4 & 12.8 & 11.9 & 11.6 \\
& $R_{c}[\mathrm{MPa}]$ & 51.2 & 50.9 & 50.2 & 49.3 \\
$\mathrm{VI}$ & $R_{f}[\mathrm{MPa}]$ & 12.3 & 12.6 & 11.8 & 11.4 \\
& $R_{c}[\mathrm{MPa}]$ & 52.7 & 52.1 & 50.4 & 50.2 \\
\hline
\end{tabular}

Table 6 Strength - Exposure to a chloride solution

\begin{tabular}{lccccc}
\hline \multirow{2}{*}{ Mix. ID } & $\begin{array}{c}\text { Exposure } \\
\text { time }\end{array}$ & $\begin{array}{c}3 \\
\text { months }\end{array}$ & $\begin{array}{c}6 \\
\text { months }\end{array}$ & $\begin{array}{c}12 \\
\text { months }\end{array}$ & $\begin{array}{c}15 \\
\text { months }\end{array}$ \\
\hline \multirow{2}{*}{ I } & $R_{f}[\mathrm{MPa}]$ & 11.2 & 12.1 & 11.0 & 9.2 \\
& $R_{c}[\mathrm{MPa}]$ & 55.2 & 53.4 & 52.1 & 51.9 \\
II & $R_{f}[\mathrm{MPa}]$ & 10.9 & 11.3 & 11.0 & 11.0 \\
& $R_{c}[\mathrm{MPa}]$ & 57.4 & 55.6 & 57.8 & 54.9 \\
III & $R_{f}[\mathrm{MPa}]$ & 10.9 & 11.7 & 11.4 & 11.2 \\
& $R_{c}[\mathrm{MPa}]$ & 52.9 & 52.1 & 52.3 & 52.1 \\
IV & $R_{f}[\mathrm{MPa}]$ & 10.8 & 11.2 & 11.4 & 10.9 \\
& $R_{c}[\mathrm{MPa}]$ & 52.3 & 53.1 & 50.5 & 50.2 \\
V & $R_{f}[\mathrm{MPa}]$ & 11.5 & 11.7 & 10.9 & 10.4 \\
& $R_{c}[\mathrm{MPa}]$ & 53.4 & 52.5 & 51.6 & 50.8 \\
& $R_{f}[\mathrm{MPa}]$ & 11.4 & 12.1 & 11.8 & 11.7 \\
VI & $R_{c}[\mathrm{MPa}]$ & 52.9 & 53.1 & 51.4 & 51.0 \\
\hline
\end{tabular}

changes are expressed as percentage, where $100 \%$ are reference values measured on specimens of the corresponding age (i.e. specimens ageing in laboratory conditions) (Figs. 1-2). b) Aggressive chloride environment

The graphs below show how the solutions influence the strength of the materials. The effect is written in percentages, where $100 \%$ represent values measured on the reference specimens of an adequate age (i.e. specimens ageing in laboratory conditions) (Figs. 3-4).

\subsection{Analysis of internal structure}

a) Ultrasonic pulse velocity test

Changes in the internal structure of materials exposed to the aggressive environments (sulphate and chloride solutions) were determined as a difference in the relative dynamic modulus of elasticity measured by the ultrasonic pulse velocity test.

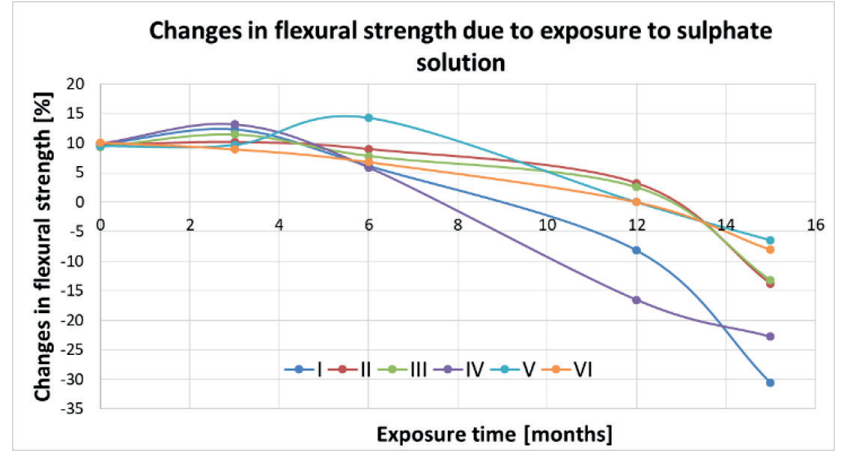

Fig. 1 Changes in flexural strength in dependence on the length of exposure to the aggressive sulphate environment

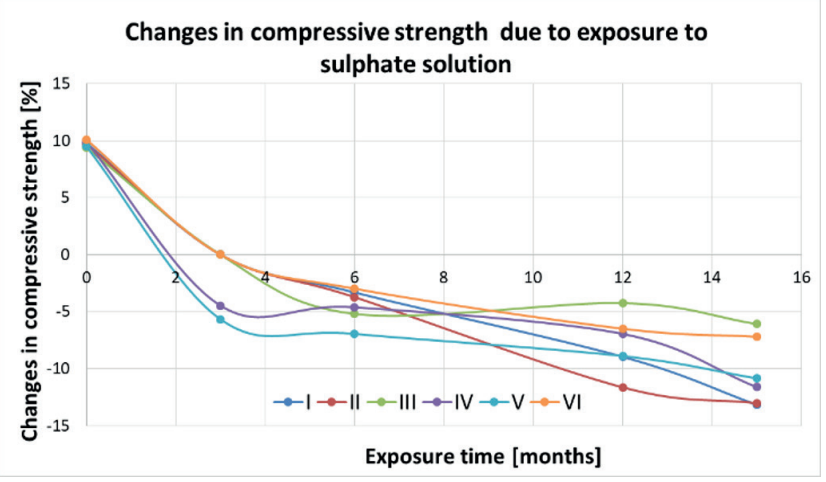

Fig. 2 Changes in compressive strength in dependence on the length of exposure to the aggressive sulphate environment

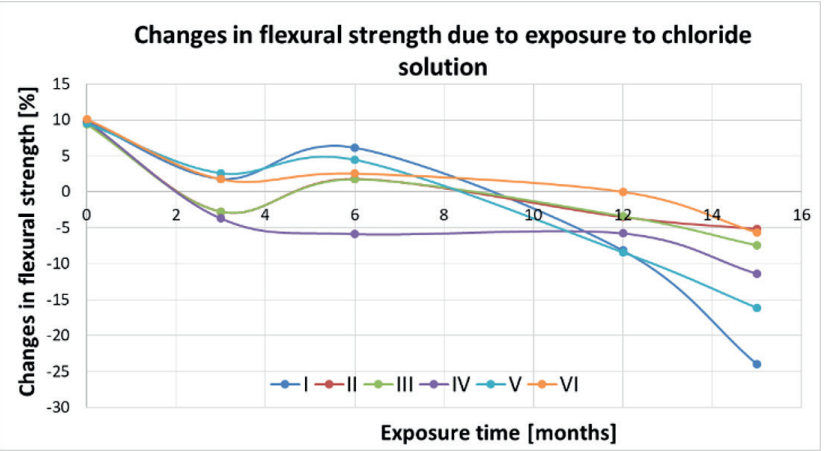

Fig. 3 Changes in flexural strength in dependence on the length of exposure to the aggressive chloride environment

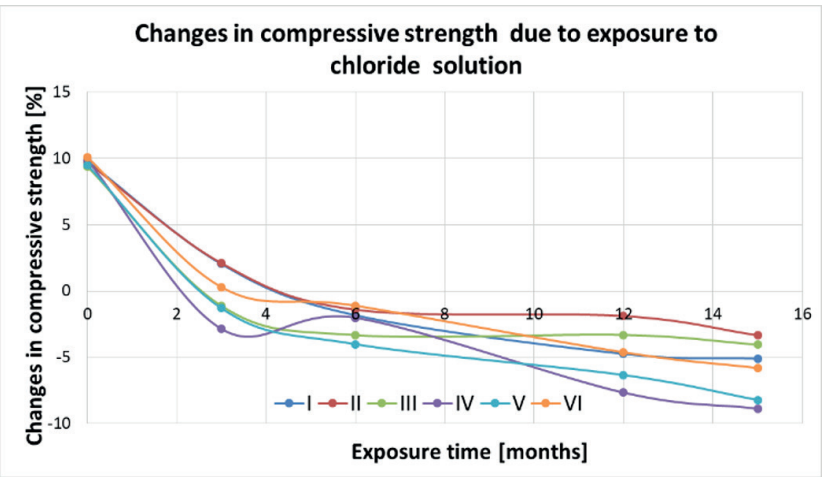

Fig. 4 Changes in compressive strength in dependence on the length of exposure to the aggressive chloride environment 


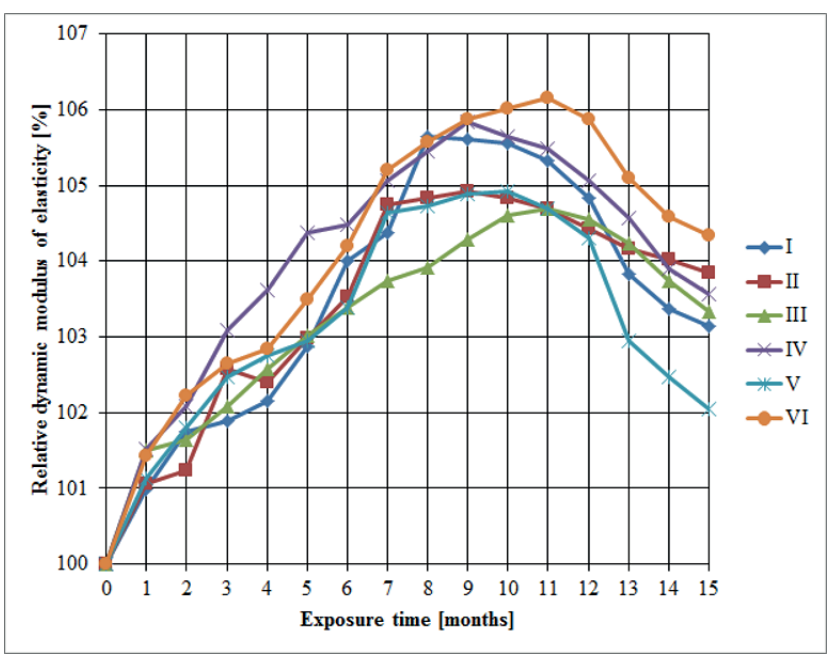

Fig. 5 Changes in relative dynamic modulus of elasticity depending on exposure time to the sodium sulphate solution

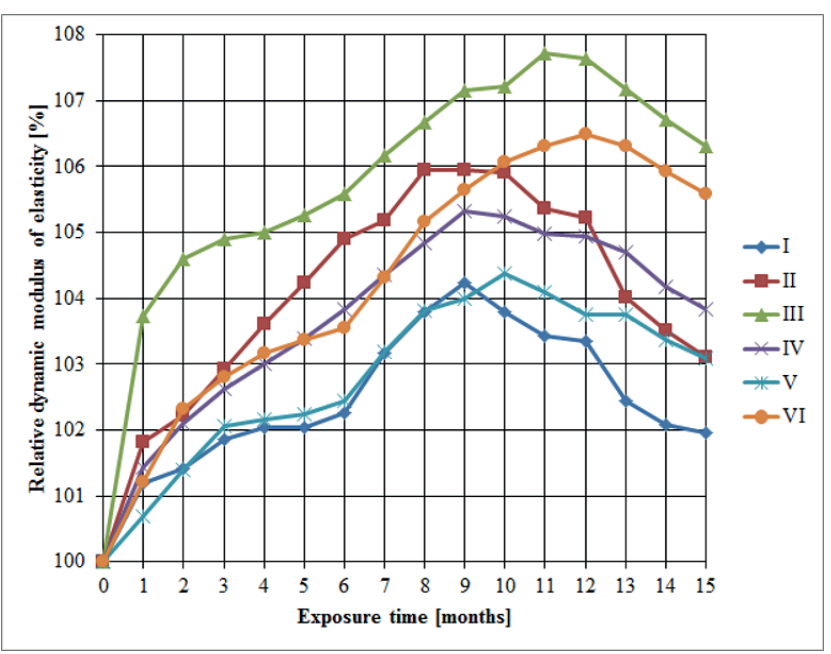

Fig. 6 Changes in the relative dynamic modulus of elasticity depending on exposure time to the ammonium chloride solution

The progress of the relative dynamic modulus of elasticity is plotted in Fig. 5 (sulphates) and Fig. 6 (chlorides). b) Mercury intrusion porosimetry and computed tomography

In order to assess the effect of CA and its ability to interact with cement hydration products the internal structure of the composites, i.e. their porosity, was examined.

New specimens were made from a cement paste. Reference specimens contained no admixtures, while the test specimens contained a $\mathrm{CA}$ at an amount of $1.5 \%$ of cement mass. They had the shape of a cylinder with the dimensions of $80 \times 100 \mathrm{~mm}$. They were left to age for 28 days in laboratory conditions. After this time, they were monitored at 28-day intervals to ascertain whether and to what extent the CA affects the capillary pore structure of the material being tested. This determination was carried out throughout the entire experiment, i.e. for 15 months.
The results of the measurements show that as the CA interacts with the hydration products, the pores are slowly eliminated; especially ones from 300 to $400 \mu \mathrm{m}$ in size. This finding was proved both by mercury intrusion porosimetry and by computed tomography.

For illustration, see the CT images of mixture III below (i.e. mixture with $1.5 \%$ of CA). These images were taken on the same specimen; Fig. 7 was taken at the age of 28 days and Fig. 8 shows the capillary pore structure at the age of 15 months.

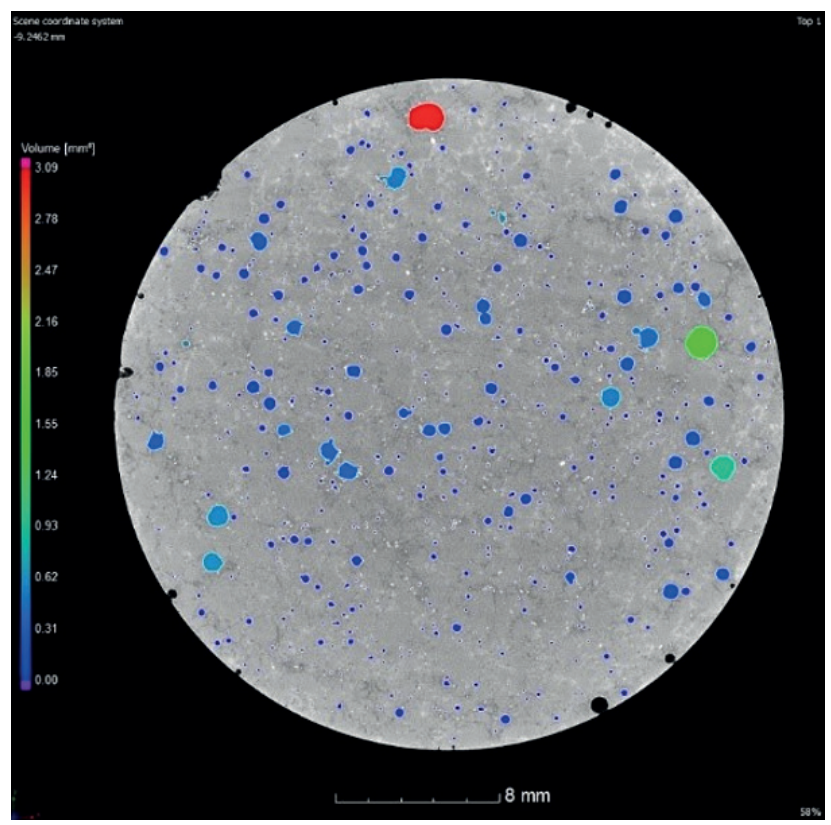

Fig. 7 Capillary pore structure of the mixture modified by the CA at an amount of $1.5 \%$ of $m_{c}$, age 28 days

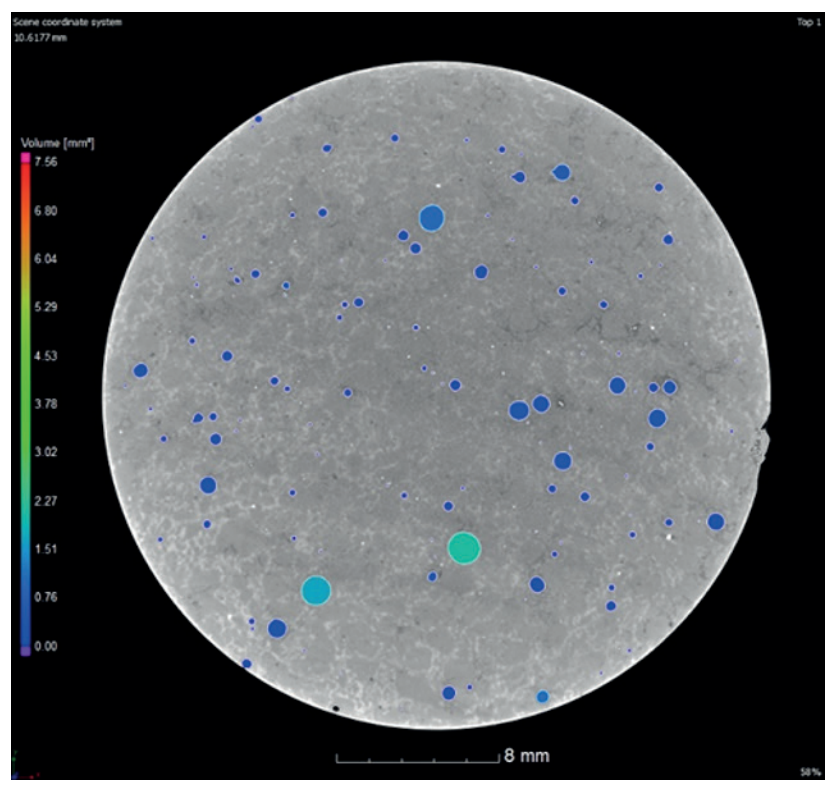

Fig. 8 Capillary pore structure of the mixture modified by the CA at an amount of $1.5 \%$ of $m_{c}$, age 15 months 


\subsection{Physical-chemical analysis}

Other analytical methods used during the experiment were XRD, DTA, and an examination by a scanning electron microscope.

Similarly to the previous case, the specimens were left to age in laboratory conditions for 28 days and then exposed to the aggressive environments. The three analyses were then performed at 28-day intervals.

Special attention was paid to the identification of new products forming as a result of the action of the aggressive environments or other negative changes taking place in the material matrix. An important aspect was the comparison between the results of the microstructure analyses performed on specimens exposed to the aggressive environments and reference specimens.

Given the fact that the strength tests registered the most marked changes after exposure to the sulphate solution, the Table 7 shows the results of an XRD analysis performed on specimens exposed to this solution.

Another of the analyses was differential thermal analysis. Its goal was mainly to supplement and expand the findings obtained by XRD.

A key finding delivered by this analysis is the clear decrease in portlandite detected in mixtures containing no CA and exposed to a sulphate solution. On the other hand, CA-modified mixtures the portlandite decrease was significantly smaller. The graph below plots the change in portlandite content brought about by the sulphate solution in dependence on mixture composition and exposure time (Fig. 9).

Another method of analysis used herein was scanning electron microscopy, which focused on a detailed examination of typical features identified in the materials, especially in those exposed to chemical attack.

Among other things, this analysis showed that corrosion products form in the capillary pore structure of the unmodified composites.

In the modified materials, the occurrence of these products is significantly limited by the effect of the CA, as are other defects, such as cracks, even after long-term exposure to aggressive environments. The figures below illustrate these findings (Figs. 10-11).

\section{Discussions}

The results of the physical-mechanical analyses can be summarized as follows:

- It was proved that the addition of a CA has virtually no effect on the fresh mixture, not even at $1.5 \%$ of cement mass. The workability was slightly influenced by the use of polypropylene fibers.
Table 7 Mineralogical composition (XRD analysis) after exposure to a sulphate solution

\begin{tabular}{|c|c|c|c|c|c|}
\hline \multirow{2}{*}{$\begin{array}{l}\text { Mix. } \\
\text { ID }\end{array}$} & \multirow{2}{*}{$\begin{array}{l}\text { Laboratory } \\
\text { conditions } \\
\text { (reference) }\end{array}$} & \multicolumn{4}{|c|}{ Time of sulphate exposure } \\
\hline & & $\begin{array}{c}3 \\
\text { months }\end{array}$ & $\begin{array}{c}6 \\
\text { months }\end{array}$ & $\begin{array}{c}12 \\
\text { months }\end{array}$ & $\begin{array}{c}15 \\
\text { months }\end{array}$ \\
\hline I & $\begin{array}{l}\text { K, Po, } \\
\text { CSH, Q }\end{array}$ & $\begin{array}{c}\text { K, Po, } \\
\text { CSH, Q }\end{array}$ & $\begin{array}{c}\mathrm{K}, \mathrm{CSH}, \\
\mathrm{A}, \mathrm{Q}\end{array}$ & $\begin{array}{c}\mathrm{K}, \mathrm{CSH}, \mathrm{A}, \\
\mathrm{E}, \mathrm{MS}, \mathrm{Q}\end{array}$ & $\begin{array}{c}\mathrm{K}, \mathrm{E}, \mathrm{MS}, \\
\mathrm{S}, \mathrm{Q}\end{array}$ \\
\hline II & $\begin{array}{c}\mathrm{K}, \mathrm{Po}, \\
\mathrm{CSH}, \text { trace } \\
\mathrm{C}, \mathrm{Q}\end{array}$ & $\begin{array}{c}\text { K, Po, } \\
\text { CSH, Q }\end{array}$ & $\begin{array}{c}\text { K, Po, } \\
\text { CSH, Q }\end{array}$ & $\begin{array}{c}\mathrm{K} \text {, trace } \\
\text { Po, CSH, } \\
\text { A, trace } \\
\text { E, Q }\end{array}$ & $\begin{array}{c}\mathrm{K}, \mathrm{CSH}, \\
\mathrm{A}, \text { trace } \\
\mathrm{E}, \mathrm{Q}\end{array}$ \\
\hline III & $\begin{array}{c}\text { K, Po, } \\
\text { CSH, Q }\end{array}$ & $\begin{array}{l}\text { K, Po, } \\
\text { CSH, Q }\end{array}$ & $\begin{array}{c}\text { K, Po, } \\
\text { CSH, Q }\end{array}$ & $\begin{array}{c}\text { K, Po, } \\
\text { CSH, A, Q }\end{array}$ & $\begin{array}{l}\text { K, Po, } \\
\text { CSH, } \\
\text { A, Q }\end{array}$ \\
\hline IV & $\begin{array}{c}\text { K, Po, } \\
\text { CSH, A, Q }\end{array}$ & $\begin{array}{l}\mathrm{K}, \mathrm{Po}, \\
\mathrm{CSH}, \\
\mathrm{A}, \mathrm{Q}\end{array}$ & $\begin{array}{l}\mathrm{K}, \mathrm{Po}, \\
\mathrm{CSH}, \\
\mathrm{A}, \mathrm{Q}\end{array}$ & $\begin{array}{c}\mathrm{K}, \mathrm{CSH}, \mathrm{E}, \\
\mathrm{S}, \mathrm{Q}\end{array}$ & $\begin{array}{c}\mathrm{K}, \text { trace } \\
\mathrm{E}, \mathrm{MS}, \\
\mathrm{S}, \mathrm{Q}\end{array}$ \\
\hline $\mathrm{V}$ & $\begin{array}{l}\text { K, Po, } \\
\text { CSH, Q }\end{array}$ & $\begin{array}{l}\text { K, Po, } \\
\text { CSH, } \\
\text { A, Q }\end{array}$ & $\begin{array}{l}\text { K, Po, } \\
\text { CSH, Q }\end{array}$ & $\begin{array}{c}\text { K, Po, } \\
\text { CSH, Q }\end{array}$ & $\begin{array}{c}\text { K, Po, } \\
\text { CSH, Q }\end{array}$ \\
\hline VI & $\begin{array}{l}\text { K, Po, } \\
\text { CSH, Q }\end{array}$ & $\begin{array}{l}\text { K, Po, } \\
\text { CSH, } \\
\text { trace } \\
\text { E, Q }\end{array}$ & $\begin{array}{l}\text { K, Po, } \\
\text { CSH, Q }\end{array}$ & $\begin{array}{l}\text { K, Po, } \\
\text { CSH, Q }\end{array}$ & $\begin{array}{c}\text { K, Po, } \\
\text { CSH, Q }\end{array}$ \\
\hline
\end{tabular}

Note: Table 6 uses the following abbreviations:

$\mathrm{K}$ - calcite; Po - portlandite; $\mathrm{CSH}$ - calcium hydro silicate gels;

$\mathrm{C}$ - carbonate complex; A - aragonite; E - ettringite, MS - monosulphate;

$\mathrm{S}$ - gypsum; Q - $\beta$ quartz.

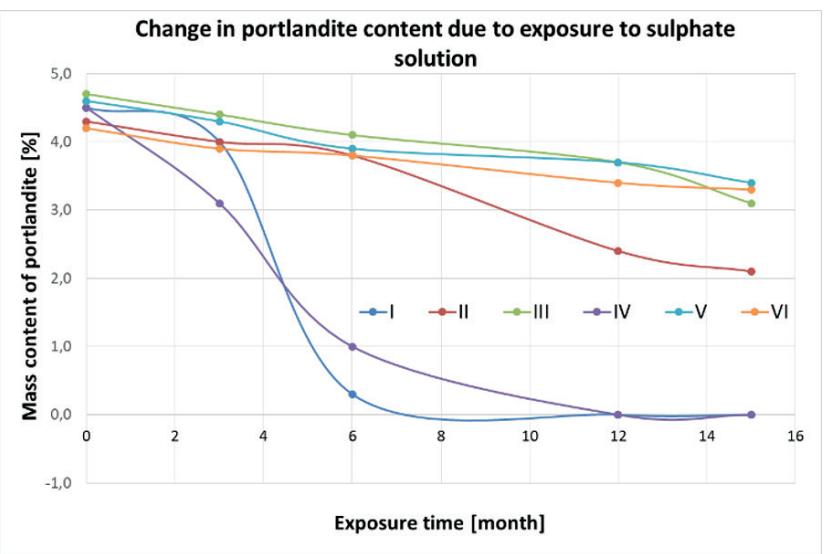

Fig. 9 Determination of the amount of portlandite in mixtures exposed to a sulphate solution

- The effect of CA on the composites' capillary porosity was tested following a methodology described in ČSN 731316 [35] Determination of moisture content, absorptivity and capillarity of concrete. A series of tests has shown that the addition of a CA improves sorption properties. This statement can be illustrated e.g. by comparing the values of absorptivity which reached $7.3 \%$ in mixture I (no CA content) as opposed to mixture III with $4.9 \%(1.5 \%$ CA content). 


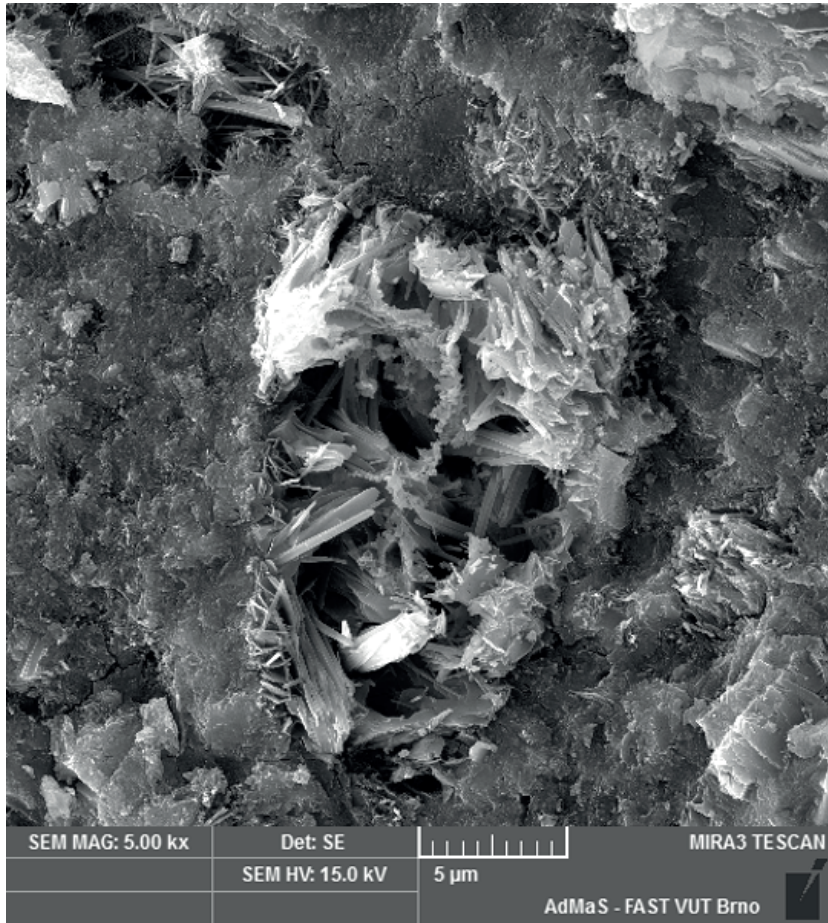

Fig. 10 A detailed view of corrosion products in the microstructure of a composite with no CA after exposure to a sulphate solution. Note the gypsum pseudomorph and druses of acicular ettringite crystals. $5000 \times$ magnification

- It was found that the effect of the aggressive environments is most strongly manifested in flexural strength, less so in compressive strength and Young's modulus.

- Strength changes in specimens exposed to sulphate attack were greater than in those exposed to ammonium chloride.

- The positive effect of CA on strength was clearly demonstrated. This statement is documented by the fact that the 15-month exposure to a sulphate solution resulted in a $30.6 \%$ decrease in flexural strength in mixture I (unmodified) or $22.8 \%$ in mixture IV (unmodified, PP fibers). However, in mixtures that contained a CA the decrease did not exceed $14 \%$ and in modified mixtures with PP fibers it was even lower.

- By extension, the benefit of CA was also confirmed in other strength characteristics (compressive strength, dynamic modulus of elasticity) in specimens exposed to the aggressive environments.

The analysis of the internal structure indicates the following:

- It was proved that exposure to the aggressive environments causes the relative dynamic modulusof elasticity to decrease, which indicates irreversible damage to the internal structure.

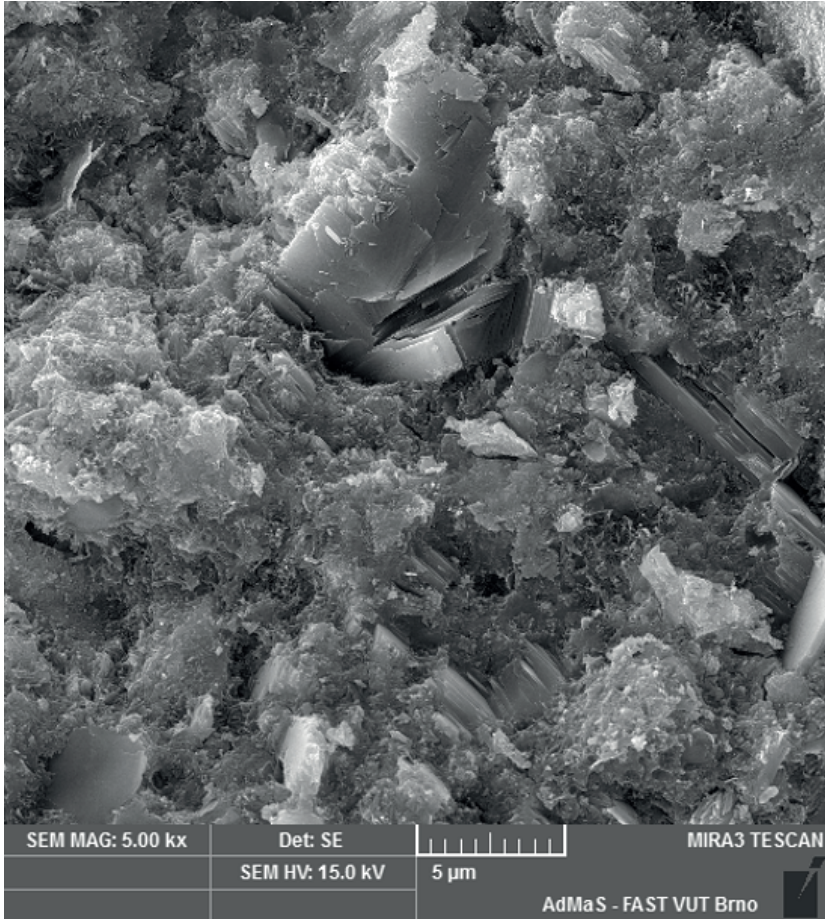

Fig. 11 View of the microstructure of a material modified by a CA. The structure is compact, without corrosion products or other defects even after sulphate attack. $5000 \times$ magnification

- For instance, after exposure to the sulphate solution, the unmodified specimens reached the inflection point after 8 months, whereas specimens with a CA reached it at approximately 11 months. A similar shift in inflection points between modified and unmodified materials was also found in the case of chloride attack. This is one of the indications of the benefit of $\mathrm{CA}$ in terms of their improving the chemical resistance of cement composites.

- The physical-chemical analyses proved that the CA can markedly limit undesirable changes taking place in the microstructure of materials exposed to aggressive environments. This is documented e.g. in the less pronounced decrease in portlandite content in specimens modified by the CA exposed to a sulphate solution brought about by a reduction in the number of corrosion products, etc.

- The process of interaction between the CA and cement matrix spans over a long period of time and it can thus be assumed that the experiment presented here was too short to capture the issue in full. Besides age, another important factor that influences changes in the character of the capillary pore structure are curing and ageing conditions, most notably humidity. This corresponds with research presented in [36]. 


\section{Conclusions}

The paper analyses the effect that crystalline admixtures have on fine-grained cement composites exposed to certain aggressive solutions.

The findings show that the use of dispersed reinforcement (fibres) affects workability to a greater degree than the addition of CA, which has only a minor influence.

Likewise, adding CA to the composites does not reduce their strength.

A series of physical-mechanical tests and physical-chemical analyses have clearly proved the positive effect they have on the chemical resistance of cement composites. This finding is in keeping with many previous

\section{References}

[1] Ferrara, L., Krelani, V., Carsana, M. "A "fracture testing" based approach to assess crack healing of concrete with and without crystalline admixtures", Construction and Building Materials, 68, pp. 535-551, 2014

https://doi.org/10.1016/j.conbuildmat.2014.07.008

[2] Yang, Y., Lepech, M. D., Yang, E.- H., Li, V. C. "Autogenous healing of engineered cementitious composites under wet-dry cycles", Cement and Concrete Research, 39(5), pp. 382-390, 2009. https://doi.org/10.1016/j.cemconres.2009.01.013

[3] Qian, S. Z., Zhou, J., Schlangen, E. "Influence of curing condition and precracking time on the self-healing behavior of Engineered Cementitious Composites", Cement and Concrete Composites, 32(9), pp. 686-693, 2010.

https://doi.org/10.1016/j.cemconcomp.2010.07.015

[4] Yang, Y., Yang, E.-H., Li, V. C. "Autogenous healing of engineered cementitious composites at early age", Cement and Concrete Research, 41(2), pp. 176-183, 2011.

https://doi.org/10.1016/j.cemconres.2010.11.002

[5] Jonkers, H. M., Schlangen, E. "Development of a bacteria-based self healing concrete", In: Walraven, J. C., Stoelhorst, D. (eds.) [pdf] Tailor Made Concrete Structures, Taylor \& Francis Group, London, UK, 2008, pp. 425-430. Available at: http://www.abece.com.br/ web/restrito/restrito/pdf/ch062.pdf

[6] Park, B., Choi, Y. C. "Self-healing capability of cementitious materials with crystalline admixtures and super absorbent polymers (SAPs)", Construction and Building Materials, 189, pp. 1054-1066, 2018.

https://doi.org/10.1016/j.conbuildmat.2018.09.061

[7] Van Tittelboom, K., De Belie, N., Van Loo, D., Jacobs, P. "Selfhealing efficiency of cementitious materials containing tubular capsules filled with healing agent", Cement and Concrete Composites, 33(4), pp. 497-505, 2011.

https://doi.org/10.1016/j.cemconcomp.2011.01.004

[8] Yang, Z., Hollar, J., He, X., Shi, X. "A self-healing cementitious composite using oil core/silica gel shell microcapsules", Cement and Concrete Composites, 33(4), pp. 506-512, 2011.

https://doi.org/10.1016/j.cemconcomp.2011.01.010 investigations [37]. The main mechanism of this is the sealing of the capillary pore system which reduces the ingress of aggressive media into the internal structure of the composite.

In terms of the service life of steel-reinforced concrete structures the effect of CA can increase over the long-term horizon.

\section{Acknowledgment}

The paper was produced with the financial support of Czech Science Foundation, project No. 16-25472S "Secondary crystallization modified cement composites and their degradation dynamics".

[9] Termkhajornkit, P., Nawa, T., Yamashiro, Y., Saito, T. "Selfhealing ability of fly ash-cement systems", Cement and Concrete Composites, 31(3), pp. 195-203, 2009. https://doi.org/10.1016/j.cemconcomp.2008.12.009

[10] Kirgiz, M. S. "Green cement composite concept reinforced by graphite nano-engineered particle suspension for infrastructure renewal material", Composites Part B, 154, pp. 423-429, 2018. https://doi.org/10.1016/j.compositesb.2018.09.012

[11] Kirgiz, M. S. "Advance treatment by nanographite for Portland pulverised fly ash cement (the class F) systems", Composites Part B, 82, pp. 59-71, 2015. https://doi.org/10.1016/j.compositesb.2015.08.003

[12] Kirgiz, M. S. "Advancements in mechanical and physical properties for marble powder-cement composites strengthened by nanostructured graphite particles", Mechanics of Materials, 92, pp. 223-234, 2016 https://doi.org/10.1016/j.mechmat.2015.09.013

[13] Kirgiz, M. S. "Fresh and hardened properties of green binder concrete containing marble powder and brick powder", European Journal of Environmental and Civil Engineering, 20(1), pp. 64-101, 2016. https://doi.org/10.1080/19648189.2016.1246692

[14] Kirg1z, M. S. "Strength gain mechanism for green mortar substituted marble powder and brick powder for Portland cement", European Journal of Environmental and Civil Engineering, 20(1), pp. 38-63, 2016. https://doi.org/10.1080/19648189.2016.1246691

[15] Kirgiz, M. S. "Strength Gain Mechanisms of Blended-Cements Containing Marble Powder and Brick Powder", KSCE Journal of Civil Engineering, 19(1), pp. 165-172, 2015. https://doi.org/10.1007/s12205-014-0557-4

[16] Kirgiz, M. S. "Effects of Blended-Cement Paste Chemical Composition Changes on Some Strength Gains of Blended-Mortars", The Scientific World Journal, 2014, Article ID 625350, 2014. https://doi.org/10.1155/2014/625350

[17] ACI Committee 212 "Report on Chemical Admixtures for Concrete", [pdf] American, Concrete Institute, Farmington Hills, MI, USA, Rep. ACI 212.3R-10, 2010. Available at: https:/www.concrete.org/ portals/0/files/pdf/previews/212.3r-10web.pdf 
[18] Roig-Flores, M., Pirritano, F., Serna, P., Ferrara, L. "Effect of crystalline admixtures on the self-healing capability of early-age concrete studied by means of permeability and crack closing tests", Construction and Building Materials, 114, pp. 447-457, 2016. https://doi.org/10.1016/j.conbuildmat.2016.03.196

[19] CSN "CSN EN 196-1 Methods of testing cement - Part 1: Determination of strength", Czech Standards Institute, Prague, Czech Republic, 2016.

[20] CSN "CSN EN 1015-3 Methods of test for mortar for masonry Determination of consistence of fresh mortar (by flow table)", Czech Standards Institute, Prague, Czech Republic, 1999.

[21] ISO "ISO 1920-7 Testing of concrete - Part 7: Non-destructive tests on hardened concrete", International Organization for Standardization, Geneva, Switzerland, 2004.

[22] ASTM "ASTM C597 Standard Test Method for Pulse Velocity Through Concrete", ASTM International, West Conshohocken, PA, USA, 2009.

https://doi.org/10.1520/C0597-09

[23] CSN "CSN EN 12504-4 Testing concrete - Part 4: Determination of ultrasonic pulse velocity", Czech Standards Institute, Prague, Czech Republic, 2005.

[24] CSN "CSN 731371 Non-destructive testing of concrete - Method of ultrasonic pulse testing of concrete", Czech Standards Institute, Prague, Czech Republic, 2011.

[25] CSN "CSN 731380 Testing the freeze-thaw resistance of concrete - Internal structural damage", Czech Standards Institute, Prague, Czech Republic, 2007.

[26] Turgut, P., Kucuk, O. F. "Comparative Relationships of Direct, Indirect, and Semi-Direct Ultrasonic Pulse Velocity Measurements in Concrete", Russian Journal of Nondestructive Testing, 42(11), pp. 745-751, 2006. https://doi.org/10.1134/S1061830906110064

[27] Awoyera, P. O., Akinwuni, I. I., Ede, A. N., Olofinnade, M. O. "Forensic Investigation of Fire-affected Reinforced Concrete Buildings", IOSR Journal of Mechanical and Civil Engineering, 11(4), pp. 17-23, 2014. https://doi.org/10.9790/1684-11441723

[28] Brozovsky, J. "Ultrasonic Pulse and Resonance Method - Evaluation of the Degree of Damage to the Internal Structure of Repair Mortars Caused by Exposure to High Temperatures", Russian Journal of Nondestructive Testing, 53(10), pp. 744-753, 2017. https://doi.org/10.1134/S1061830917100047
[29] Brozovsky, J. "Evaluation of Frost Resistance of Calcium Silicate Masonry Units with Ultrasonic Pulse and Resonance Methods", Russian Journal of Nondestructive Testing, 50(10), pp. 607-615, 2010. https://doi.org/10.1134/S1061830914100039

[30] Olowofoyeku, A. M., Olutoge, F. A. "Domestication Of Pundit Non-Destructive Test Chart in Measuring Compressive Strength of Normal Strength Concrete Subjected to Elevated Temperature", [pdf] Australian Journal of Basic and Applied Sciences, 7(1), pp. 1-6, 2013. Available at: http://ajbasweb.com/old/ajbas/2013/ January/1-6.pdf

[31] Dufka, A., Matousek, M., Drochytka, R. "Zpráva č. 30-31: Vysokotlaká rtutová porozimetrie a počítačová tomografie" (Report Nr. 30-31: Mercury intrusion porosimetry and X-ray computed tomography), Brno University of Technology, Faculty of Civil Engineering, Brno, Czech Republic, 2006. (in Czech)

[32] Wang, Y.-S., Dai, J.-G. "X-ray computed tomography for pore-related characterization and simulation of cement mortar matrix", NDT\&E International, 86, pp. 28-35, 2017.

https://doi.org/10.1016/j.ndteint.2016.11.005

[33] Birgul, R. "Monitoring macro voids in mortar by X-ray computed tomography", Nuclear Instruments and Methods in Physics Research A, 596, pp. 459-466, 2008. https://doi.org/10.1016/j.nima.2008.08.080

[34] Ponikiewski, T., Katzer, J., Bugdol, M., Rudzki, M. "Determination of 3D porosity in steel fibre reinforced SCC beams using X-ray computed tomography", Construction and Building Materials, 68, pp. 333-340, 2014. https://doi.org/10.1016/j.conbuildmat.2014.06.064

[35] CSN "CSN 731316 Determination of moisture content, absorptivity and capillarity of concrete", Czech Standards Institute, Prague, Czech Republic, 1990

[36] Peek, A., Goh, D., Khiong, F. W. "Xypex Waterproofing - Singapore Arts Centre Project", Taywood Engineering Ltd., Singapore, Rep. 1303/97/8426, 1997.

[37] Matousek, M., Drochytka, R. "Atmosférická koroze betonů" (Atmospheric Corrosion of Concrete), 1st ed., IKAS+ČKAIT, Praha, Czech Republic, 1998. (in Czech) 